\title{
PERAN GENDER DALAM MENANGANI PERMASALAHAN SAMPAH
}

\section{Oleh :}

\author{
Tri Harningsih, M.Si
}

\begin{abstract}
ABSTRAK
Sampah pada dasarnya merupakan suatu bahan yang terbuang atau dibuang dari suatu sumber hasil aktivitas manusia maupun proses-proses alam yang mempunyai nilai ekonomi tinggi jika dimanfaatkan dengan baik dan benar. Tetapi jika dibiarkan saja, maka sampah akan mempunyai nilai ekonomi yang negatif karena dalam penanganannya baik untuk membuang atau membersihkannya memerlukan biaya yang cukup besar.

Sampah dan pengelolaannya kini menjadi masalah yang kian mendesak di Indonesia, sebab apabila tidak dilakukan penanganan yang baik akan mengakibatkan terjadinya perubahan keseimbangan lingkungan yang merugikan atau tidak diharapkan sehingga dapat mencemari lingkungan baik terhadap tanah, air dan udara. Oleh karena itu untuk mengatasi masalah pencemaran tersebut diperlukan penanganan dan pengendalian terhadap sampah.

Pengelolaan sampah secara terpadu berarti bahwa dalam mengelola sampah harus diperhatikan segala aspek yang terkait sebagai satu kesatuan yang terintegrasi luas dan holistik, yaitu sampah dikelola tidak berdasarkan aspek kebersinggungan dan keterkaitannya secara erat dengan aspek-aspek lain, seperti kesehatan, tata ruang, pendidikan, politik dan kamtibmas, kemiskinan, peluang usaha, investasi, produksi, teknologi, ketenagakerjaan, lingkungan hidup serta perempuan.
\end{abstract}

Kata kunci : sampah, kesehatan, teknologi, lingkungan hidup dan tenaga kerja 


\section{Pendahuluan}

Semakin bertambahnya penduduk, maka sampah yang dihasilkannya pun akan bertambah pula seiring dengan kegiatan yang dilakukan oleh masyarakat. Selain itu dapat pula dicermati bahwa jenis dan kualitas sampah juga bertambah seiring dengan kehidupan masyarakat yang cenderung konsumeristis. Kondisi ini memaksa pemerintah dan lembaga terkait mencari suatu solusi untuk mengelola sampah dengan baik dan benar berdasarkan pengetahuan yang sebetulnya relatif minim. Namun sayang, niat baik pemerintah itu masih jauh dari memadai bila diukur dari sistem dan metode pengelolaan sampah yang efektif, aman, sehat, ramah lingkungan, dan ekonomis.

Hal ini didukung juga dari sangat minimnya apresiasi yang diberikan kepada mereka yang bekerja di sektor persampahan, minimnya perhatian dan kurang cukup tersedianya kebijakan-kebijakan, perencanaan, program-program, anggaran dan kredit yang memadai untuk menangani sampah secara serius, sistematis, dan terukur. Menyebabkan penanganan sampah masih terkesan sesuatu yang business as usual dan rutin serta masih dipandangnya sampah sebagai barang buangan yang menjijikkan. Sehingga penanganannya pun dipahami hanya sebatas urusan memindahkan, membuang, dan memusnahkan dengan cara yang sangat tidak aman dan cenderung mencemari lingkungan. Penistaan terhadap sampah merembet juga kepada orang-orang yang berkecimpung di bidang persampahan seperti pemulung, tukang sampah dan petugas kebersihan. Sampah baru menjadi perhatian belakangan ini setelah timbulnya ledakan kasus dan bencana, seperti terjadi di Bantargebang, Bojong Gede dan Leuwi Gajah.

Keadaan ini membawa akibat semakin beratnya tekanan terhadap media lingkungan, yang pada gilirannya mengharuskan dilakukannya pergeseran pendekatan dari pendekatan ujung-pipa (end-pipe of solution) ke pendekatan sumber. Dengan pendekatan sumber, maka sampah ditangani pada hulu sebelum sampah itu sampai ke tempat pengolahan akhir (hilir). Pada prinsipnya, pendekatan sumber menghendaki dikuranginya produk sampah. yang akan dikirim ke tempat pengolahan akhir, dengan cara, antara lain, penerapan $4 \mathrm{R}$ (replace, reduce, re-use, recycling). 
Dengan pergeseran pendekatan dalam pengelolaan sampah berarti pula perubahan paradigma pengelolaan sampah. Dengan pergeseran pendekatan dan perubahan pradigma, maka pengelolaan sampah meliputi pengendalian timbulan sampah, pengumpulan, pengangkutan dan penanganan akhir sampah yang dilakukan secara terpadu. Pengelolaan sampah secara terpadu berarti bahwa dalam mengelola sampah harus diperhatikan segala aspek yang terkait sebagai satu kesatuan yang terintegrasi luas dan holistik, yaitu sampah dikelola tidak berdasarkan aspek kebersinggungan dan keterkaitannya secara erat dengan aspekaspek lain, seperti kesehatan, tata ruang, pendidikan, politik dan kamtibmas, kemiskinan, peluang usaha, investasi, produksi, teknologi, ketenagakerjaan, lingkungan hidup serta perempuan.

Keterlibatan perempuan dalam proyek-proyek penanganan sampah akan memberdayakan kaum perempuan, karena perempuan memiliki sifat dasar yang suka memelihara dan menjaga kebersihan lingkungan khususnya apabila kegiatan proyek tersebut dihubungkan dengan kegiatan-kegiatan yang berhubungan dengan peningkatan pendapatan dan sumber daya produktif seperti penghematan air bersih, listrik, pemanfaatan bahan selain minyak bumi dan menjaga kebersihan lingkungan. (Meutia Hatta, 2007).

\section{Kondisi Pengelolaan Sampah di Indonesia}

Jumlah penduduk Indonesia telah meningkat menjadi hampir dua kali lipat selama 25 tahun terakhir, yaitu dari 119,20 juta jiwa pada tahun 1971 bertambah menjadi 198,20 juta jiwa pada tahun 1996 dan bertambah kembali menjadi 204,78 juta jiwa pada tahun 1999. Jika tingkat pertumbuhan penduduk ini tidak mengalami perubahan positif yang drastis maka pada tahun 2020 jumlah penduduk Indonesia diperkirakan akan mencapai 262,4 juta jiwa dengan asurnsi tingkat pertumbuhan penduduk alami sekitar 0,9\% per tahun. Pertambahan penduduk ini diperkirakan tidak akan tersebar merata, tetapi akan terkonsentrasi di daerah perkotaan. Hal ini dikarenakan kawasan perkotaan merupakan tempat yang sangat menarik bagi masyarakat untuk mengembangkan kehidupan sosial 
ekonomi. Selain itu, pembangunan ekonomi Indonesia melalui jalur industrialisasi berpengaruh langsung terhadap pembangunan perkotaan.

Secara umum kondisi jenis sampah memperlihatkan karakteristik yang khas yaitu sampah memiliki komposisi terbesar adalah sampah organik, dengan nilai rata-rata sebesar 79,164 prosen, sedangkan sampah non organik hanya sebesar 20,836 \% dengan besaran simpangan baku sebesar 9,5\%. Dengan komposisi sampah yang demikian dapat digunakan sebagai dasar pertimbangan perencanaan pemanfaatan sampah. Jika 79,16\% sampah tersebut dapat dimanfaatkan sebagai kompos, maka beban sampah sebagai sampah non organik hanya bersisa 20,836 \% dari total sampah yang harus masuk ke TPA. Jika dari $20,836 \%$ sampah non organik tersebut, rata-rata komposisi plastik dari sampah mencapai 10,55 \%, maka dapat dimanfaatkan dalam kegiatan daur ulang dan atau pemanfaatan kembali (recycle dan reuse), sehingga jumlah sampah yang harus dikelola di dalam TPA akan semakin berkurang. Dengan demikian sarana transportasi dan alat berat yang harus disediakan atau dibutuhkan untuk kegiatan di dalam TPA juga akan semakin berkurang. (www.terranet.or.id/konferensi/ 0307-sampah/draft_RUU_isi.pdf, 3 Juni 2008).

Pada tahun 1980 persentase jumlah penduduk kota di Indonesia adalah 27,29\% dari jumlah penduduk Indonesia, sementara pada tahun 1990 persentase tersebut bertambah menjadi 30,93\%. Diperkirakan pada tahun 2020 persentase jurnlah penduduk kota di Indonesia mencapai 50\% dari jumlah penduduk Indonesia. Akibat dari semakin bertambahnya tingkat konsumsi masyarakat serta aktivitas lainnya adalah bertambahnya pula buangan/limbah yang dihasilkan. Limbah/buangan yang ditimbulkan dari aktivitas dan konsumsi masyarakat yang lebih dikenal sebagai limbah domestik telah menjadi permasalahan lingkungan yang harus ditangani oleh pemerintah dan masyarakat itu sendiri. Limbah domestik tersebut, baik itu limbah cair maupun limbah padat menjadi permasalahan lingkungan karena secara kuantitas maupun tingkat bahayanya mengganggu kesehatan manusia, mencemari lingkungan, dan mengganggu kehidupan makhluk hidup lainnya (Bapedal, 2001). 
Khusus untuk sampah atau limbah padat rumah tangga, peningkatan jumlah sampah yang dihasilkan di Indonesia diperkirakan akan bertambah 5 kali lipat pada tahun 2020. Rata-rata produksi sampah tersebut diperkirakan meningkat dari 800 gram per hari per kapita pada tahun 1995 menjadi 910 gram per hari per kapita pada tahun 20003. Hal ini diakibatkan bukan saja karena pertumbuhan penduduk tetapi juga karena meningkatnya timbulan sampah per kapita yang disebabkan oleh perbaikan tingkat ekonomi dan kesejahteraan.

Melihat data di atas, maka pola pembuangan sampah yang dilakukan dengan sistem TPA (tempat pembuangan akhir) sudah tidak relevan lagi dengan lahan yang semakin sempit dan pertambahan penduduk yang pesat, sebab bila hal ini terus dipertahankan akan membuat volume sampah yang terus bertambah dan membutuhkan biaya pengelolaan yang tinggi pula. Pembuangan yang dilakukan dengan pembuangan sampah secara terbuka dan di tempat terbuka juga berakibat meningkatnya intensitas pencemaran.

Penanganan model pengelolaan sampah secara menyeluruh adalah meliputi penghapusan model TPA pada jangka panjang karena dalam banyak hal pengelolaan TPA (tempat pembuangan sampah) masih sangat buruk mulai dari penanganan air sampah (leachet) sampai penanganan bau yang sangat buruk. Cara penyelesaian yang ideal dalam penanganan sampah adalah dengan cara membuang sampah sekaligus memanfaatkannya sehingga selain membersihkan lingkungan, juga menghasilkan kegunaan baru. Hal ini secara ekonomi akan mengurangi biaya penanganannya (Murthado dan Said, 1987).

Secara umum pengelolaan sampah selama ini dilakukan melalui 3 tahapan kegiatan, yakni : pengumpulan, pengangkutan dan pembuangan akhir/pengolahan. Tahapan kegiatan tersebut merupakan suatu sistem, sehingga masing-masing tahapan dapat disebut sebagai sub sistem. Aboejoewono (1985) menggambarkan secara sederhana tahapan-tahapan dari proses kegiatan dalam pengelolaan sampah sebagai berikut : 


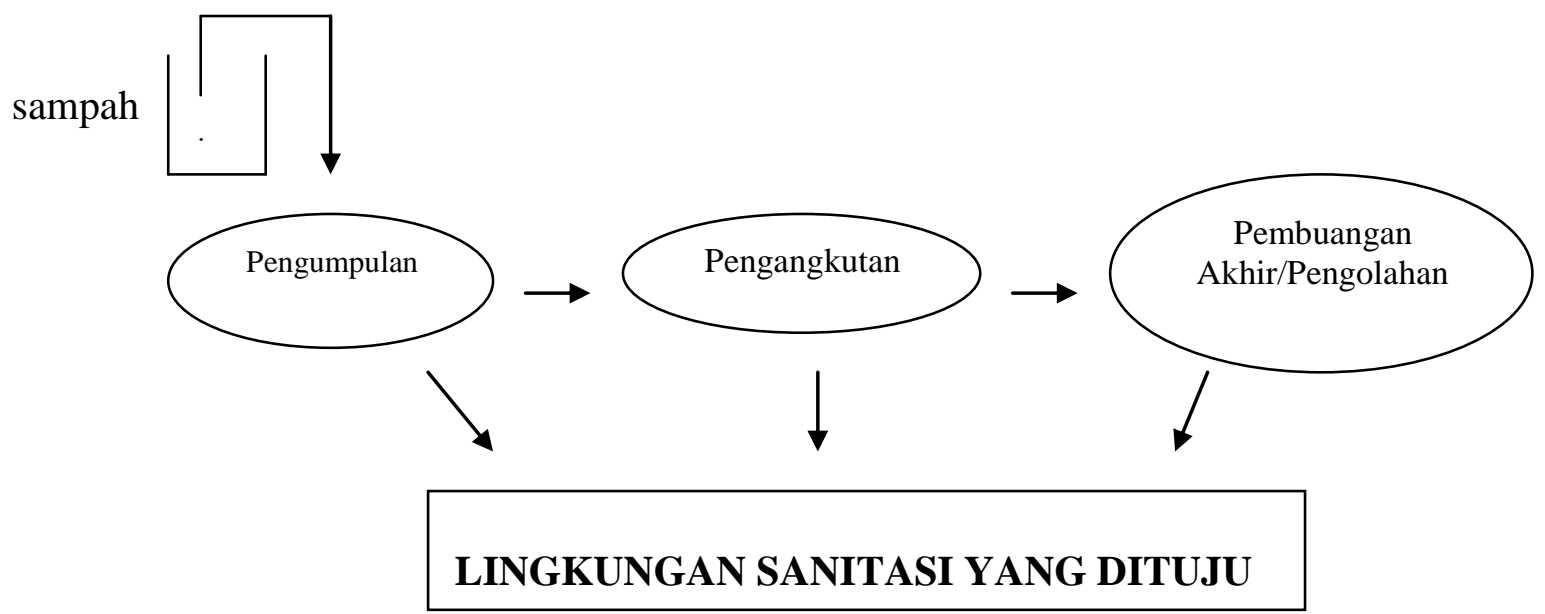

Gambar 1. Tahapan kegiatan pengelolaan sampah sistem lama Menurut Sidik, dkk (1985), beberapa permasalahan yang mungkin timbul dalam sistem penanganan sampah tradisional yakni :

1. Dari segi pengumpulan sampah dirasa kurang efisien karena mulai dari sumber sampah sampai ke tempat pembuangan akhir, sampah belum dipilah-pilah sehingga kalaupun akan diterapkan teknologi lanjutan berupa komposting maupun daur ulang perlu tenaga untuk pemilahan menurut jenisnya sesuai dengan yang dibutuhkan, dan hal ini akan memerlukan dana maupun menyita waktu.

2. Pembuangan akhir ke TPA dapat menimbulkan masalah, jika lahan yang tersedia tidak ada. Semakin bertambah jumlah penduduk, maka sampah akan menjadi semakin bertambah baik jumlah dan jenisnya. Hal ini akan semakin bertambah juga luasan lahan bagi TPA.

3. Pembuangan sistem open dumping dapat menimbulkan beberapa dampak negatip terhadap lingkungan. Pada penimbunan dengan sistem anarobik landfill akan timbul leachate di dalam lapisan timbunan dan akan merembes ke dalam lapisan tanah di bawahnya. Leachate ini sangat merusak dan dapat menimbulkan bau tidak enak, selain itu dapat menjadi tempat pembiakan bibit penyakit seperti : lalat, tikus dan lainnya.

4. Pembuangan dengan cara sanitary landfill, walaupun dapat mencegah timbulnya bau, penyakit dan lainnya, tetapi masih memungkinkan 
muncul masalah lain yakni timbulnya gas yang dapat menyebabkan pencemaran udara. Gas-gas yang mungkin dihasilkan adalah : methan, $\mathrm{H}_{2} \mathrm{~S}, \mathrm{NH}_{3}$ dan lainnya. Gas $\mathrm{H}_{2} \mathrm{~S}$ dan $\mathrm{NH}_{3}$ walaupun jumlahnya sedikit, namun dapat menyebabkan bau yang tidak enak sehingga dapat merusak sistem pernafasan tanaman dan membuat tanaman kekurangan gas oksigen dan akhirnya mati.

5. Belum maksimalnya usaha pemasaran bagi kompos yang dihasilkan dari proses pengomposan sampah dan upaya sistem daur ulang menjadi barang-barang yang bernilai ekonomi tinggi.

\section{Peran Masyarakat Dalam Menangani Sampah}

Sampah pada dasarnya merupakan suatu bahan yang terbuang atau dibuang dari suatu sumber hasil aktivitas manusia maupun proses-proses alam yang mempunyai nilai ekonomi tinggi jika dimanfaatkan dengan baik dan benar. Tetapi jika dibiarkan saja, maka sampah akan mempunyai nilai ekonomi yang negatif karena dalam penanganannya baik untuk membuang atau membersihkannya memerlukan biaya yang cukup besar.

Sampah dan pengelolaannya kini menjadi masalah yang kian mendesak di Indonesia, sebab apabila tidak dilakukan penanganan yang baik akan mengakibatkan terjadinya perubahan keseimbangan lingkungan yang merugikan atau tidak diharapkan sehingga dapat mencemari lingkungan baik terhadap tanah, air dan udara. Oleh karena itu untuk mengatasi masalah pencemaran tersebut diperlukan penanganan dan pengendalian terhadap sampah.

Masalah yang sering muncul dalam penanganan sampah adalah masalah biaya operasional yang tinggi dan semakin sulitnya ruang yang pantas untuk pembuangan. Sebagai akibatnya maka akan dibutuhkan biaya operasional yang tinggi. Dari dampak tersebut, kebanyakan kota-kota di Indonesia hanya mampu mengumpulkan dan membuang $\pm 60 \%$ dari seluruh produksi sampahnya. Dari $60 \%$ ini, sebagian besar ditangani dan dibuang dengan cara yang tidak saniter, boros dan mencemari (Daniel et al., 1985). 
Untuk mendapatkan tingkat efektifitas dan efisiensi yang tinggi dalam penanganan sampah maka dalam pengelolaannya harus cukup layak diterapkan yang sekaligus disertai upaya pemanfaatannya sehingga diharapkan mempunyai keuntungan berupa nilai tambah. Untuk mencapai hal tersebut maka perlu pemilihan cara dan teknologi yang tepat, perlu partisipasi aktif dari masyarakat sumber sampah berasal dan mungkin perlu dilakukan kerjasama antar lembaga pemerintah, perguruan tinggi dan pondok pesantren sebagai pusat basis masyarakat muslim.

Konsep rencana pengelolaan sampah perlu dibuat dengan tujuan untuk mengembangkan suatu sistem pengelolaan sampah yang modern, dapat diandalkan dan efisien dengan tehnologi yang ramah lingkungan. Dalam sistem tersebut harus dapat melayani seluruh penduduk, meningkatkan standar kesehatan masyarakat dan memberikan peluang bagi masyarakat dan pihak swasta untuk berpartisipasi aktif. Pendekatan yang digunakan dalam konsep rencana pengelolaan sampah ini adalah meningkatkan sistem pengelolaan sampah yang dapat memenuhi tuntutan dalam paradigma baru pengelolaan sampah.

Sistem manajemen persampahan yang dikembangkan harus merupakan sistem manajemen yang berbasis pada masyarakat yang dimulai dari pengelolaan sampah di tingkat rumah tangga. Setiap rumah tangga memisahkan sampah mereka ke dalam tiga tempat (tong) sampah. Masing-masing diisi oleh sampah organik, anorganik yang dapat didaur ulang (seperti : gelas, plastik, besi, kertas dan sebagainya). Sampah plastik dikumpulkan kemudian dikirim ke industri yang mengolah sampah plastik. Demikian halnya sampah kertas dikumpulkan kemudian dikirim ke industri pengolah kertas. Sedangkan sampah organik disatukan untuk kemudian dikomposkan untuk digunakan sebagai pupuk pertanian.

Rencana pengelolaan sampah perlu adanya metode pengolahan sampah yang lebih baik, peningkatan peran serta dari lembaga-lembaga yang terkait dalam meningkatkan efisiensi dan efektivitas pengelolaan sampah, meningkatkan pemberdayaan masyarakat, peningkatan aspek ekonomi yang mencakup upaya 
meningkatkan retribusi sampah dan mengurangi beban pendanaan pemerintah serta peningkatan aspek legal dalam pengelolaan sampah.

Partisipasi masyarakat dalam pengelolaan sampah merupakan aspek yang terpenting untuk diperhatikan dalam sistem pengelolaan sampah secara terpadu. Cohen dan Uphof (1977) mengemukakan bahwa partisipasi masyarakat dalam suatu proses pembangunan terbagi atas 4 tahap, yaitu : a) partisipasi pada tahap perencanaan, b) partisipasi pada tahap pelaksanaan, c) partisipasi pada tahap pemanfaatan hasil-hasil pembangunan dan d) partisipasi dalam tahap pengawasan dan monitoring. Masyarakat senantiasa ikut berpartisipasi terhadap proses-proses pembangunan bila terdapat faktor-faktor yang mendukung, antara lain : kebutuhan, harapan, motivasi, ganjaran, kebutuhan sarana dan prasarana, dorongan moral, dan adanya kelembagaan baik informal maupun formal (www.menlh.go.id/i/art/pdf_1130481609.pdf, 3 Juni 2008)

\section{Peran Gender Dalam Proyek Penanganan Sampah}

Proyek-proyek penyediaan air, sanitasi dan penanganan sampah yang ditangani oleh ADB lebih dari beberapa dekade terakhir telah membuktikan adanya hubungan positif yang kuat antara perhatian pada gender dan partisipasi kaum perempuan, di satu pihak, dengan tingkat keberhasilan proyek dan kesinambungan pengelolaan penyediaan air, sanitasi dan penanganan sampah (Aflina:2003).

Wakeman (1995) dan Fong et al. (1996) menjelaskan fokus pada gender memiliki efek ganda kaum perempuan memiliki peran utama dalam mengumpulkan, mengangkut, menggunakan dan mengelola lingkungan dan memajukan praktek-praktek saniter. Fokus pada gender memberi manfaat yang lebih besar dari sekedar kemampuan proyek untuk menyediakan air, sanitasi dan pengelolaan sampah yang baik, pengoperasian dan pemeliharaan yang lebih baik, efisiensi biaya dan kesadaran terhadap kesehatan.

Adapun manfaat-manfaat tersebut, termasuk, antara lain:

- Manfaat ekonomi: Akses yang lebih baik pada lingkungan akan memberi kaum perempuan waktu yang lebih banyak untuk melakukan aktivitas 
mendatangkan pendapatan, menjawab kebutuhan-kebutuhan anggota keluarga, atau memberikan kesejahteraan dan waktu luang untuk kesenangan mereka sendiri. Perekonomian, secara keseluruhan, dapat pula memberikan berbagai manfaat.

- Manfaat kepada anak-anak: Kebebasan dari pekerjaan mengumpulkan dan mengelola sampah yang memakan waktu dapat membuat anak-anak, khususnya anak perempuan untuk bersekolah. Oleh sebab itu, dampaknya diharapkan dapat mencapai antar generasi.

- Pemberdayaan terhadap kaum perempuan: Keterlibatan dalam proyekproyek penanganan sampah akan memberdayakan kaum perempuan, khususnya apabila kegiatan proyek tersebut dihubungkan dengan kegiatankegiatan yang berhubungan dengan peningkatan pendapatan dan sumber daya-sumber daya produktif . ( www.idepfoundation.org/Indonesia. 3 Juni $\underline{2008)}$ 


\section{DAFTAR RUJUKAN}

Aboejoewono, A. 1985. Pengelolaan Sampah Menuju ke Sanitasi Lingkungan dan Permasalahannya; Wilayah DKI Jakarta Sebagai Suatu Kasus. Jakarta.

Daniel, T. S., Hasan, P. dan Vonny, S. 1985. Tehnologi Pemanfaatan Sampah Kota dan Peran Pemulung Sampah : Suatu Pendekatan Konseptual. PPLH ITB. Bandung.

Murtadho, D. dan Sa'id, E. G. 1988. Penanganan Pemanfaatan Limbah Padat. Sarana Perkasan. Jakarta.

Pusat Informasi Lingkungan Hidup, 2001. State of The Environment Report Indonesia 2001, Bapedal, hal. 3-11.

Sidik, M. A., Herumartono, D. dan Sutanto, H. B. 1985. Tehnologi Pemusnahan Sampah dengan Incinerator dan Landfill. Direktorat Riset Operasi Dan Manajemen. Deputi Bidang Analisa Sistem Badan Pengkajian Dan Penerapan Teknologi. Jakarta.

www.terranet.or.id/konferensi/0307-sampah/draft_RUU_isi.pdf, tanggal akses 3 Juni 2008

www.idepfoundation.org/Indonesia/idep_wastegroup.html. tanggal akses : 3 Juni 2008

www.menlh.go.id/i/art/pdf_1130481609.pdf, 3 Juni 2008 